University of Pennsylvania Carey Law School

Penn Law: Legal Scholarship Repository

Faculty Scholarship at Penn Law

2016

\title{
The Short- and Long-Run Effects of Private Law Enforcement: Evidence from University Police
}

\author{
Paul Heaton \\ University of Pennsylvania Carey Law School \\ Priscillia Hunt \\ RAND Corporation \\ John M. MacDonald \\ University of Pennsylvania \\ Jessica Saunders \\ RAND Corporation
}

Follow this and additional works at: https://scholarship.law.upenn.edu/faculty_scholarship

Part of the Criminology and Criminal Justice Commons, Law and Economics Commons, Law and Society Commons, Law Enforcement and Corrections Commons, Policy Design, Analysis, and Evaluation Commons, and the Public Administration Commons

\section{Repository Citation}

Heaton, Paul; Hunt, Priscillia; MacDonald, John M.; and Saunders, Jessica, "The Short- and Long-Run Effects of Private Law Enforcement: Evidence from University Police" (2016). Faculty Scholarship at Penn Law. 1856.

https://scholarship.law.upenn.edu/faculty_scholarship/1856

This Article is brought to you for free and open access by Penn Law: Legal Scholarship Repository. It has been accepted for inclusion in Faculty Scholarship at Penn Law by an authorized administrator of Penn Law: Legal Scholarship Repository. For more information, please contact PennlawIR@law.upenn.edu. 


\title{
The Short- and Long-Run Effects of Private Law Enforcement: Evidence from University Police
}

\author{
Paul Heaton \\ University of Pennsylvania Law School and RAND \\ 3501 Sansom St., Philadelphia, PA 19104 \\ pheaton@law.upenn.edu (215) 746-3353 \\ Priscillia Hunt \\ RAND Corporation \\ 1776 Main Street, PO Box 2138, Santa Monica, CA 90407 \\ phunt@rand.org (301) 393-0411 \\ John MacDonald \\ University of Pennsylvania Department of Criminology \\ 3718 Locust Walk, Philadelphia, PA 19104 \\ johnmm@sas.upenn.edu (215) 746-3623 \\ Jesssica Saunders* \\ RAND Corporation \\ 1776 Main Street, PO Box 2138, Santa Monica, CA 90407 \\ jsaunder@rand.org (301) 393-0411
}

\footnotetext{
* Corresponding author: Saunders (jsaunder@rand.org). This paper was produced as part of the RAND Corporation's self-initiated research program. Samantha Cherney provided excellent research assistance. We express appreciation to Aaron Chalfin for helpful comments and Chief Marlon Lynch from UCPD for providing data and feedback. The contents of the paper are solely the responsibility of the authors.
} 


\begin{abstract}
Over a million people in the United States are employed in private security and law enforcement, yet very little is known about the effects of private police on crime. The current study examines the relationship between a privately-funded university police force and crime in a large U.S. city. Following an expansion of the jurisdictional boundary of the private police force, we see no short-term change in crime. However, using a geographic regression discontinuity approach, we find large impacts of private police on public safety, with violent crime in particular decreasing. These contradictory results appear to be a consequence of delayed effect of private police on crime.
\end{abstract}

Keywords: Private police; police effectiveness; geographic regression discontinuity 


\section{Introduction}

With constrained public budgets, falling crime rates, and high pay rates of sworn officers, there is increasing debate about whether there is an appropriate role for the private sector in delivering public safety. As of May 2014, over 1.05 million people in the U.S are employed as private police (such as private detectives, investigators, and security guards), up 8\% from $2004 .^{1}$ That is slightly more than all people employed in computer systems design and related services, and more than three times the number of people working in motor vehicle parts production. With the rise in private police, however, there have been debates about the lack of their accountability to the public, use of excessive force, and violations of constitutional rights (Davis et al. 2010; Stenning 2000; Boghosian 2005; Prenzler et al. 1996). Despite significant investments in and potential legal implications of private police operating in public spaces, there are only a handful of studies that examine the effectiveness of any type of private police on public safety outcomes.

The few studies in the area find that private police enhance public safety outcomes, with campus police in particular decreasing crime across almost every measure (MacDonald, Klick, and Grunwald 2012), and private security employed for business improvement districts improved public safety outcomes as well (MacDonald et al. 2010, Brooks 2008, Cook and MacDonald 2011). However, the generalizability of these findings to other communities, the time frame over which any gains from private policing are realized, and the comparative impacts of private versus conventional police remain poorly understood.

This paper seeks to provide new evidence on the impact of private police on crime, exploiting a unique setting that permits a credible examination of the causal effect of police both in the short and long-run. We focus on the University of Chicago Police Department (UCPD),

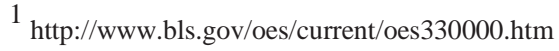


the largest private police department in Chicago (Reaves, 2008) operating in a comparatively crime-prone region of a major U.S. city, which is dense (Chicago Tribune 2014) and racially diverse (Northwestern Univeristy Center for Healthcare Equity 2011), and subject to the same types of crimes as other Chicago neighborhoods (Chicago Tribune 2014). The UCPD is an excellent test case for examining the effect of private police on crime because they are highly professionalized and accredited department working in a very well-defined and discrete geographic space that extends well beyond campus and into the surrounding neighborhoods of the South Side of Chicago.

Using two methods, a difference-in-difference (DD) approach exploiting temporal and spatial variation in jurisdictional powers and a geographic regression discontinuity (GRD) design exploiting the location of the UCPD jurisdictional border, this study examines the effect that UCPD had on crime and violence. Using the DD approach, this study finds the short-term effect of the expansion of private police was not statistically significant. The GRD design allows us to examine the long-term effect of UCPD by using cumulative crime levels on either side of the UCPD jurisdiction border. Using this approach, we find a large and statistically significant effect - areas just outside the border of the UCPD patrol area experienced 55\% more crime total, and 63\% greater violent crime. Given the UCPD represent an approximate doubling of police presence relative to surrounding neighborhoods with 92 FTE and 3 PTE working within a 6.5 mile jurisdiction in 2014, these effects translate to an elasticity of overall crime with respect to police of about -0.7 , and a violent crime elasticity of -0.9 , somewhat higher than the elasticities estimated for conventional police (Chalfin and McCrary 2013). These differing estimates can be reconciled if it takes a substantial period of time-potentially many years--for criminals to recognize and respond to the ongoing presence private police. 


\section{Background}

\subsection{The Role and Scope of Private Policing}

Private police refer to law enforcement bodies funded and operated by non-governmental entities. Many of the spaces commonly viewed as public, such as shopping malls, residential areas, parks, and educational campuses, are in fact controlled by private entities (Stenning 2000, Wakefield 2008, Joh 2005, Shearing and Stenning 1981, Jones and Newburn 1999). Referred to as "mass private property," these spaces, which are privately-owned but routinely used and frequented by the public, now make up a substantial portion of the public space in urban areas (Stenning 2000). The owners of these areas may hire their own "police" to ensure both the safety of the public who frequent their space, and the protection of their business interests.

Private police or security typically follow a different license, registration, background check, and training than public police officers, and these regulations vary by state. Once licensed and approved, private police have the authority to patrol, stop, detain, and search individuals without probable cause. Most private security officers and investigators do not have full powers of arrest, however, and are typically unarmed (IACP, 2002).

In many settings, lines have blurred between the private police and public police (Wakefield 2008, D’Alessio, Eitle, and Stolzenberg 2005, Joh 2005, Kakalik and Wildhorn 1971, University of Chicago Department of Safety and Security 2013, Nalla and Heraux 2003, Shearing and Stenning 1981, 1983, Spitzer and Scull 1977, Stenning 2000, Wakefield 2002), and many of the remaining distinctions may be more theoretical than practical. Private and public officers both seek to reduce crime and increase safety, although the "client base for private police [is] smaller" (Nalla and Heraux 2003). Thus the private police may be more concerned with 
creating a favorable business climate for their employers than with justice. The private police are also subject to different oversight and accountability laws than traditional police (Stenning 2000), which may create unequal services that disproportionately benefit the private sector.

The size of the private police or security industry has stabilized after years of substantial growth. Between 1988 and 1997, the size of private police forces grew by almost 800\%, while the public police force grew by only $15 \%,{ }^{2}$ and has leveled off since then. There remain approximately 300,000 more private than the public police nationwide. ${ }^{3}$ Some researchers and legal scholars believe that the increase in private police, including campus police, may be part of the wider trend of privatizing government services (for example Joh 2005, Kempa, Stenning, and Wood 2004, Sklansky 1999), in line with the privatization of prisons (Sklansky 1999, Joh 2005), and, to a lesser extent, the judicial branch (Savas 1987, Sklansky 1999). Others believe that private policing has emerged due to the changing nature of the built environment, such as the increasing desire to have outdoor private property open for public access and use.

\subsection{Campus Police: Private or Public Police?}

Rather than traditional public police or private security, this study focuses on a particularly prevalent form of private law enforcement-campus police. Of the U.S. universities and fouryear colleges with more than 2,500 students, nearly three quarters employ sworn personnel — officers with full arrest powers granted by the government — with some forces consisting of more than 300 officers (Reaves 2008). While some may have full police powers, they are funded by the colleges and universities that they protect, which distinguishes them from public police. In addition to granting campus law enforcement agencies greater policing power, there has been a

\footnotetext{
2 Bureau of Labor Statistics (BLS), Protective Service Occupations.

3 According to the BLS, as of May 2013, there were 740,340 public patrol officers or detectives, and 1,066,730 private security guards in the United States (2013).
} 
concurrent increase in the size of the jurisdictions under their control, extending beyond their respective campuses (Peak, Barthe, and Garcia 2008). This may be part of the larger movement towards privately-funding police and security officers to protect individuals and property.

Although campus police fall under the umbrella of private police, they may have more in common with the public police than traditional private security. Campus police departments, as they are increasingly known, are often fully accredited law enforcement agencies employing sworn police officers. Nearly 90\% of departments employ armed patrol officers (Reaves, 2008). Campus law enforcement agencies also engage in a variety of formal police duties, including uniformed patrols, arrests, and investigations (Peak, Barthe, and Garcia 2008). The activities performed by campus law enforcement agencies includes investigations, crime prevention, parking enforcement, training, crime reporting under the Clery Act (Janosik and Gregory 2003), public event coordination, planning, narcotics, traffic and accident investigations, dealing with hazardous materials, canine, and SWAT (Reaves 2008, Peak, Barthe, and Garcia 2008).

While the responsibilities and activities of campus police and public police are quite similar, they also differ in other respects that may be relevant for analysis in this study. Campus police agencies are more likely than local departments to conduct community-relations skills assessments of new recruits, whereas local departments are more likely to require written aptitude testing and physical screening. In addition, while more campus officers are collegeeducated, public police officers have more police academy and in-service training requirements (Reaves 2008).

\subsection{Measuring the Effect of Police on Crime}

Standard economic models of crime (Becker 1993; Ehrlich, 1981; Ehrlich, 2010) posit that rational individuals trade off the gains from crime with the costs of punishment and commit 
crime when the expected benefit outweighs the expected costs. Potential victims invest in protective measures designed to increase the cost of committing an offense and thus reduce incentives to commit crime (Cook 1986). Such measures can include individual efforts such as installation of locks and alarms or avoiding higher crime areas, but also investments in collective law enforcement activities, both public and private.

Optimal choices regarding the level of private policing activity can take into account that private police may have a wider scope of objectives than traditional police. Some research suggests that private police are concerned with preventing or reducing losses and, accordingly, are more concerned with monitoring, surveillance, and prevention than with arrest and punishment (Joh 2004). The private police in this study exist in a comparatively high crime area of the city and there is significant concern about conventional crime such as robbery or burglary. Therefore, we anticipate that one of its primary objectives is traditional street crime reduction, and in this respect, UCPD may be atypical in comparison to other private police forces that are more focused on loss prevention.

In the context of Chicago and the UCPD, some blocks are patrolled by both public and private police. This additional supply of policing services relative to areas patrolled by only the CPD is hypothesized to increase the expected cost of offending by raising probability of getting caught, and thus reduce the supply of crime. For blocks that become newly covered by the UCPD, whether we observe shifts in crime depends not only on the effectiveness of private police, but also on the speed with which behavioral change occurs. For example, when UCPD officers first occupy a new expansion area, they may require time to build relationships with people in the community or confidential informants and learn about the contours of the built environment. Moreover, traditional police may respond to the presence of private police by 
reallocating effort towards other areas. In that case, private police substitute for public police, therefore attenuating any positive effect private police have on reducing crime.

Ultimately, whether private police affect crime is an empirical question. The basic problem of measuring the effect of police on crime is not a new one, although our focus on private rather than traditional law enforcement is novel. A persistent empirical challenge identified by past researchers (Marvell and Moody 1996) is to cleanly separate the impacts of police from the myriad other factors that affect crime rates. Beyond this typical difficulty due simultaneity and omitted variable bias, and additional obstacle that arises in this context is that of reverse causality — the size of the police force may not only affect crime, but also respond to changes in the crime rate through the political process. ${ }^{4}$

To resolve some of these methodological challenges to estimating the effect of police forces on crime, researchers have turned to a number of quasi-experimental research designs. Levitt (1997, 2002) and McCrary (2002) exploit the fact that police hiring often occurs around mayoral and gubernatorial elections, and the timing of these elections across jurisdictions is not determined by crime rates. Corman and Mocan (1996) and Buonanno and Mastrobuoni (2012) make use of the fact that hiring decisions are often made long before new officers can be deployed due to training lags, meaning that the timing of when officers start may be not be correlated to current crime rates. Di Tella and Schargrodsky ( 2004), Klick and Tabarrok (2005), and Draca, Machin, and Witt ( 2011) focus on personnel reallocations that occur in repsonse to terrorist threats, the timing of which is unrelated to patterns of underlying street crime. Evans and Owens (2007) use a large federal hiring program that created new officer positions in

4 Chalfin and McCrary (Chalfin and McCrary 2013) identify an additional source of bias in estimates that exploit cross-jurisdiction variation in police force size and crime-measurement error. They demonstrate that common sources of information about police staffing levels show inconsistencies which lead to downward biased estimates of the effects of police on crime. Because we consider data from a single jurisdiction, our analysis is not subject to the measurement error problem they highlight. 
numerous jursidictions across the U.S., with slots determined in a manner unrelated to preexisting crime. These studies focus on different lags in the impact of police on crime, yet each found that an increase in police presence or force size led to a decrease in crime.

Based on the existing literature, we might expect a substantial decline in street crime in areas with substantial private police presence. However, we would only expect such an effect magnitude if private police are as effective at reducing crime as traditional police, a proposition that has not been well tested to date, and one that is evaluated empirically in this study. Perhaps closest to the present study is MacDonald, Klick, and Grunwald (2012), which uses a geographic discontinuity design to test the effects of extra police provided by a private university, finding significant impacts. However, that study is only cross sectional and does not have the advantage of being able to observe what happens to crime before and after the patrol boundary of the private police was altered. As a result it could only estimate the long-term effect of the private police on neighborhood crime. By contrast, we are able to capitalize on the natural experiment that occurred with the expanded geographic coverage of a private university police force to estimate the short-term effect of adding extra private police to a set of neighborhood blocks, and a geographic regression discontinuity to test the effect of extra police on crime over a long-term.

\section{University of Chicago Police Department}

The UCPD was formally established in the 1960s, and granted full police powers through an Illinois Law, the Private College Campus Police Act (110 ILCS 1020). The police department is CALEA ${ }^{\circledR}$-accredited, and operates 24 hours a day, seven days a week. ${ }^{5}$ Officers are required to complete a series of background checks and training including, background investigation, written and medical exams, oral interview, psychological test, drug screen and physical fitness test

5 http://safety-security.uchicago.edu/police/. 
(POWER Test), training consistent with Illinois Law Enforcement Training and Standards Board (ILETSB), weeks of Chicago Police Academy training, and finally the UCPD Field Training Program. The department has separate, additional emergency and investigation phone lines from the Chicago Police Department (CPD); although individuals can always call 9-1-1 for services from CPD.

The size of the UCPD police force grew over most of the period analyzed in this study. Specifically, the number of full time-equivalent (FTE) officers grew on average 7 percent annually between 2000 and 2010, from 83 to 145 FTEs, and fell again to 80 FTEs in $2012 .{ }^{6}$ Uniform Crime Reports (UCR) police employee data indicates there was one police officer for every 212 people in the city of Chicago. As of 2010, the UCPD had one officer for every 464 people within its jurisdiction. Therefore, by 2010, the number of officers per capita was 50\% greater within the UCPD zone than outside the UCPD zone.

The UCPD's patrol area is not limited to the campus itself, but instead extends beyond the campus border into the surrounding community, which includes student housing, commercial areas, and residential neighborhoods. The area monitored by UCPD has expanded over time and is currently approximately 6.5 square miles, containing over 65,000 residents; although formal documentation and details of its size and expansion are spotty (Larson 2012). Importantly for the purpose of this study, the off-campus areas patrolled by the UCPD are similar in many ways to the surrounding neighborhoods patrolled exclusively by the CPD. In particular, there are few qualitative differences in the quality of the housing stock, types of housing (primarily condos,

6 Unpublished data provided by the University of Chicago Police Department. 
townhomes, and apartments), school assignments, or other neighborhood characteristics at the boundary of the UCPD patrol area, a reality we demonstrate more formally later. ${ }^{7}$

Over the past decade the UCPD has expanded its primary jurisdiction from $39^{\text {th }}$ to $64^{\text {th }}$ Streets and Cottage Grove Avenue to Lake Shore Drive. As shown in Figure 1, the first expansion of UCPD authority occurred in October 2001 and included 78 Census blocks (shown in blue) south of the original UCPD area. And in April 2004, UCPD expanded its jurisdictional boundary by 105 additional Census square blocks north of the original UCPD area. There was a third expansion in May 2012, which was not included in these analyses because there is not a long enough follow-up period (highlighted in orange). These expansions were in response to student, faculty, and other security officers concern that the crime in the surrounding area was directly impacting school safety and the viability of the institution (Larson, 2012).

Since crime data is not available before the beginning of the UCPD in the 1960s, this study only analyzes the impact of the two expansions that occurred in 2001 and 2004. Consistent crime definitions and data collection methods started in 2001, so there are only 9 months of reliable pre-period crime data before the first expansion occurred in October 2001. We also investigate whether there are any effects on crime over time in these expansion zones.

\section{Empirical Strategy}

\subsection{Short-run Effect: Natural Experiment}

The first identification strategy of this study exploits the change in UCPD boundaries over time. In October 2001, 52 populated Census blocks went from being CPD-only to additionally being under UCPD jurisdiction (Expansion I), and in April 2004, an additional 77 populated Census blocks became UCPD jurisdiction (Expansion II). These two areas are

7 Perhaps the main exceptions are portions of the western and southeastern boundary of the UCPD patrol area which are contiguous to large parks. 
considered the "treatment" blocks. We define the control area as the 1,954 populated Census blocks surrounding UCPD jurisdictions where UCPD never had jurisdiction, including parts of the Douglas, Grand Boulevard, Greater Grand Crossing, Hyde Park, Kenwood, Oakland, South Shore, Washington Park and Woodlawn neighborhoods. We conduct a differences-in-differences (DD) estimation in which the change in average monthly crime rates before-and-after the introduction of UCPD in the treatment blocks is compared to the change in monthly crime in the control blocks. Models include block and month-year fixed effects, and specifications adjust standard errors for clustering at the block-level. Monthly block-level crime counts are the outcome, and the model is estimated using Poisson regression to account for the count nature of the data. ${ }^{89}$

A key assumption of the DD methodology is that the outcome in the treatment and control group is assumed to follow the same time trend in the absence of the treatment (parallel trends assumption). In order to analyze pre-trends, this study also includes a DD model with leads and lags (Stevenson and Wolfers, 2006). Specifically, pertaining to time relative to the first month of UCPD entering a jurisdiction, we include a series of dummies coding the month-year of jurisdiction expansion and each month pre- and post-jurisdiction expansion.

\subsection{Long-Run Effect: Geographic Regression Discontinuity Design}

The second identification strategy focuses on the longer-term effect of UCPD and exploits the geographic discontinuity caused by having extra private police on one side of the patrol zone and not the other. If the UCPD impacts crime, we would expect to see different crime

8 Since Census blocks are relatively small (approximately 60 people per block), there are many zeroes in the data, which might affect the precision of the estimates. We also estimate the DD regressions using as Census block groups (with approximately 1,000 people per block group). Unlike with the smaller blocks, however, there are block groups that overlap jurisdictional boundaries. Results are available from the authors and are similar.

${ }^{9}$ As noted by a number of authors, including Karaca-Mandic, Norton, and Dowd (2012), the interpretation of DD coefficients is somewhat more complicated in a Poisson count model due to its nonlinearity. Puhani (2012) points out, however, that coefficients on the DD interaction term can be used to examine the sign and significance of the treatment effect in a nonlinear model under fairly general conditions. 
patterns in their patrol zone relative to areas outside of their patrol zone. However, simple comparisons of crime between the blocks patrolled by UCPD to those not controlled by UCPD may not reveal the true causal effect of police because of potentially unobserved differences in neighborhood characteristics between the two areas of the city. To mitigate bias that might arise due to omitted neighborhood characteristics, we adopt a regression discontinuity design that focuses on changes in crime immediately surrounding the UCPD patrol border, which in most cases, is miles away from the main campus.

The UCPD boundaries seem well-suited to this analytic strategy because they are precisely defined, known to the police and public, and not contiguous with any campus border, but are largely unrelated to neighborhood or other geographic boundaries that would potentially affect crime patterns. By focusing attention of border areas, we ensure that the "treated" areas with additional private police are as comparable as possible to the comparison areas with only traditional police. For example, the volume of unattended cars parked on the street is likely to affect the number of vehicle thefts that occur on a particular block, and this characteristic is unobserved and thus cannot be directly controlled in our analysis. While there may be significant differences on average in vehicular parking patterns around the UCPD campus versus the comparison neighborhoods, it seems less plausible that parking patterns would vary significantly between two blocks that are situated next to one another in the same neighborhood, but which lie of differing sides of the UCPD border. Thus, a comparison between two border blocks might potentially offer a better opportunity to obtain an unbiased estimate of the effect of the campus police. The GRD approach offers an opportunity to estimate such differences across a large number of blocks within a well-established statistical framework. 
In our context the running variable for the GRD design is distance to the border. We note, however, that unlike in the traditional RD design, in our case treatment (private police protection) and control status are not assigned by a scoring mechanism with a known functional form. Moreover, for the RD approach to recover the true causal effect of private police, we require that there be no geographic spillovers resulting from the existence of the boundary. If, for example, criminals concentrate just outside of the UCPD patrol boundary in an effort to avoid detection, the border area may provide a poor counterfactual for the amount of crime that would be expected in the UCPD area absent the UCPD, and we might overstate the impacts of private police.

We estimate the change in the crime at the discontinuity using regression methods typically applied to regression discontinuity modeling; in particular, we consider crime counts as an outcome and model these as a function of an indicator as to whether a block lies outside the UCPD boarder and additional controls, with the controls including functions capturing the distance to the border. We consider a range of alternative parameterizations of the model, including varying the degree of the polynomial in distance and applying local linear regression. We also conduct falsification tests using the same variables and modeling strategy with geocoded data on business licenses and vehicle traffic as outcomes, which should not be associated with the UCPD boundaries.

\section{Data}

Street-level crime incident data were taken from the publicly-available CPD Citizen Law Enforcement Analysis and Reporting (CLEAR) website (www.gis.chicagopolice.org), which includes crime incidents from 2001 onwards reported to the police and geocoded to the closest block. Individual events are classified into crime categories by CPD. This study analyzes four 
major categories, following the Federal Bureau of Investigation's Uniform Crime Reporting Program - a sum of total reported crime; and the disaggregates of violent crime (including the Part I crimes of homicide, criminal sexual assault, robbery, and aggravated assault), property crime (including the Part 1 crimes of burglary, larceny, motor vehicle theft, and arson), and public violence (Part I violent crimes and firearms-related crimes occurring outside of a business or residence, excluding domestic violence). The overall reported crime measure includes Part II less serious crimes. We also examined Part II crimes separately but decided against presenting the findings here since they are much more susceptible bias in reporting and recording (Gove, Hughes, and Geerken 1985).

Street-level incident data were aggregated to the Census block level, and none of the blocks are split across both sides of the UCPD boundary. The comparison blocks are drawn from the community areas surrounding the UCPD jurisdiction most similar in character to Hyde Park, including Douglas, Grand Boulevard, Greater Grand Crossing, Kenwood, Oakland, South Shore, Washington Park and Woodlawn; blocks in Hyde Park that are not in the UCPD jurisdiction are also included in the comparison area. Data on block-level demographics, socio-economic characteristics, and population were taken from the 2000 and 2010 US Censuses, and linearly interpolated to generate annual estimates.

\subsection{Short-Run Effect: Natural Experiment}

For the DD analysis, a block/month panel is built from January 2001 to December 2010, and the evolution of crime in the expansion areas is analyzed compared to control areas over time. The total analytical sample includes 2,082 populated Census blocks with at least one crime over the period analyzed; 1,953 blocks fall within the control group (blocks never patrolled by UCPD because they are outside the expansions zones) and 129 are in the treatment group (UCPD 
expansion I is 52 blocks and expansion II area is 77 blocks). On average, approximately 1.7 crimes are committed in the CPD Census blocks per month and 1.4 crimes are committed in the UCPD blocks. The age and gender distributions are similar between the two groups, but the population and ethnic distribution differ. Population per block is greater in the UCPD area and there is a greater proportion of blacks in the CPD area.

Figure 2 illustrates crime trends for total crime in each of the two areas analyzed over the period investigated from January 2001 to December 2010. The thin vertical line indicates the timing of Expansion I (October 2001), and the thick vertical line indicates Expansion II (April 2004). Both jurisdictions have similar seasonal patterns of crime, and the difference between the two jurisdictions narrowed over the period investigated. Importantly for the DD design, the crime pre-trends appear to be similar between the two groups.

\subsection{Long-Run Effect: Geographic Regression Discontinuity Design}

For the GRD analysis, the data is pooled into a single cross-section of blocks by summing the number of crimes committed within each block over the period April 2004 and May 2012. This means the GRD analysis is based on only the period after the phased in expansion so that there are no jurisdictional changes during our observation period.

Table 1 presents summary statistics describing the demographic characteristics of the UCPD blocks based upon 2010 Census data. We also report RD estimates of the change in each demographic characteristic at the boundary, along with each estimate's associated standard error and p-value. There are few differences in the race or other demographics of the resident population, their income, or housing characteristics comparing the UCPD blocks to nearby blocks outside of the patrol zone. Where differences exist, in practical terms the disparities are small. Because of the large number of tested characteristics, even absent any true discontinuities, 
some statistically significant coefficients may arise due to chance alone when using conventional significance levels. If the UCPD areas do not differ systematically from the control areas at the discontinuity, then the p-values of the differences in characteristics should be uniformly distributed, and an omnibus Kolmogorov-Smirnov test for balance across the full set of characteristics listed in the table fails to reject the null hypothesis of balance $(p=.99)$. This suggests the CPD blocks near the boundary are similar to UCPD blocks near the boundary.

\section{Results}

\subsection{Short-Run Effect: Natural Experiment}

Results of our DD regressions analyzing the effect of the UCPD on total crime and then separately by crime type are presented in Table 2. The first column indicates that there was no statistically significant effect on monthly crime identified in the areas annexed by the UCPD. When estimating the effect on violent, property and other crimes separately, the difference in the logs of expected counts is found to be similar between the CPD-only blocks and UCPD blocks, holding all else constant in the model. Lastly, focusing on any violent crime occurring out in public, results indicate the effect of UCPD is statistically insignificant. When analyzing the effect of each expansion area separately, results are consistent with the main findings, and no statistically significant impacts are apparent.

We next replicate the previous DD analyses but this time consider lead and lag effects of expanding jurisdiction. Including leads allows us to observe potential confounding effects of preexisting trends and test for possible endogeneity in jurisdiction expansion, and examining lags offers an opportunity to more finely assess the dynamics of post-expansion crime. One month pre-expansion is the excluded dummy for each expansion area and is set equal to zero in our 
presentation of results (Figure 3). We present point estimates as the dashed line and the 95 percent confidence interval in the solid lines.

These trends support the findings reported in Table 2 of no statistically significant impact additional private police on crime in the short- to medium-run. Crime begins to trend downward in the treated areas approximately 80 months from jurisdiction expansion, although these shifts are not statistically significant. ${ }^{10}$ To the extent that private police impact crime, such impacts may only be discernable over the longer-term. For this analysis we turn to the GRD results.

\subsection{Long-Run Effect: Geographic Regression Discontinuity Design}

Given the similarities in demographics and other characteristics of the blocks immediately beyond the UCPD border to those areas within the border (Table 1), absent any long-run impact of private police on crime, we might expect crime rates to be similar across the two areas as well. Figure 4 shows the relationship between average block distance to the boundary and the total number of violent crimes over the period of investigation, along with the polynomials of best fit. As the figure shows, there is a higher density of crimes just beyond the UCPD border. There is no simple explanation for the drop in crime observed at the boundary other than the fact that areas within the boundary are patrolled by extra private police.

Results of our GRD regressions analyzing the effect of a block residing on the UCPD side of a border on four categories of crime are presented in Table 3. For our baseline model we include no demographic controls but account for distance to the border using local linear regression, which has some desirable statistical properties relative to other methods of

\footnotetext{
10 We test a number of other time variables in order to identify the speed with which crime declined as a result of the two expansions. We use quarterly- and annual-level data, and test time dummies, time trends, and nonlinear time effects. Results are statistically insignificant overall, as well as for expansion I and expansion II separately.
} 
accounting for distance. ${ }^{11}$ The treatment variable indicates being outside of the UCPD patrol area, so a positive estimate indicates a reduction in crime from the UCPD. Results are statistically significant and indicate that CPD blocks had 68.7 more crimes than UCPD blocks in total over eight years, from April 2004 through May 2012, which corresponds to 55\% more crime (mean number of crimes per year in the UCPD and CPD patrol zones were 126 and 162, respectively). There was also a statistically significant impact on violent crime at the $1 \%$ level, such that there were 9.7 more violent crimes per block on the CPD side, which represents 63\% fewer violent crimes (mean number of violent crimes in UCPD and CPD patrol zones was 11 and 17, respectively). Overall, it does not appear that the UCPD had a statistically significant impact on property crime or violent crime committed only in the public space, although the point estimates suggest potentially large impacts on these crimes in a practical sense. On an annual basis, blocks within the UCPD patrol boundaries had an average of 8.5 fewer crimes per year, of which 1.2 were violent crimes.

Table 4 demonstrates that these findings are robust to a number of logical specification changes to the RD design. Specification 1 estimates the same model using logged crime and finds similar results. Controlling for a multitude of socio-economic characteristics (column 2), results become only marginally significant for total crime, yet remain statistically significant for violent crimes at the $1 \%$ level; there were approximately 9 more violent crimes per block in the CPD area. The robust model, which generates confidence intervals robust to differing bandwidth choices for the local polynomial regression according to the procedure of Calonico, Cattaneo and Titiunik (2014), indicates an even greater effect of UCPD than found in the base model. The

\footnotetext{
${ }^{11}$ Gelman and Imbens (2014) and Imbens and Lemieux (2008) provide a more detailed discussion of the advantages of local linear regression in this context.
} 
impact of UCPD was 83.2 fewer crimes per block overall, and a statistically significant fewer 11.3 violent crimes per block on the UCPD side of the border.

Specifications 4 and 5 use conventional polynomials rather than local linear regression to account for distance and yield similar results. In Specification 6, we estimates a "donut"-RD design by omitting blocks less than 50 meters from the border, while in Specification 7, we only include blocks within 400 meters of the border in the analysis, ensuring identification comes solely through areas near to the border. In both cases the estimated impacts for overall and violent crime remain qualitatively similar, although the smaller number of observations in these specifications renders the estimates appreciably less precise. Finally, in Specification 8 we measure distance based upon block centroids versus block edges, and again observe large impacts on overall and violent crime. Across the various specifications we see consistent evidence that private police reduce violent crime, and some evidence of an impact of overall crime.

To put these magnitudes in perspective, we can roughly equate the impacts above to elasticities of police with respect the crime, the conventional metric reported in studies of the effects of police. Although precise manpower data for the UCPD over the entire period are elusive, in 2014 the UCPD had around 92 FTE and 3 PTE working within its 6.5 mile jurisdiction in 2014, which represents an approximate doubling of police presence relative to neighboring areas of the city, assuming no crowding out. Then, these effects translate to an elasticity of overall crime with respect to police of about -0.7 , and a violent crime elasticity of 0.9, somewhat higher than the elasticities estimated for conventional police.

If the GRD design is an appropriate method for modeling the effects of CPD presence, we might see changes in crime across the border, but we shouldn't expect to detect changes in 
other outcomes not logically connected with police presence. To examine this, we geocoded data on business licenses and traffic volume obtained from the City of Chicago Data Portal and applied a similar GRD analysis to these outcomes as a falsification test. Those falsification tests did not identify any measurable discontinuity along the UCPD boundary in either business licenses or traffic volume. ${ }^{12}$ The lack of an effect when examining these other outcomes supports the use of the GRD methodology as a way of measuring the influence of the CPD.

\section{Discussion}

Our analysis indicates that the introduction of private police in a new patrol area initially had no measurable effect of crime, yet, after sufficient time has passed, the presence of private police is associated with economically meaningful reductions in crime. How do we reconcile these findings with those of papers such as Di Tella and Schargrodsky (2004), Klick and Tabarrok (2005), and Draca, Machin, and Witt (2011), all of which demonstrate using credible quasi-experiments that invovled similarly large shifts in police presence that criminal activity can repsond rapidly to changes in police presence?

One possiblity is that culture is key, and there are cultural or other environmental differences between Chicago and the other locations studied that cause the effects of police in this study to be different from those observed other places. However, given that the existing studies span multiple countries and time periods and yet get fairly consistent impacts, it seems less likely that cultural differences alone can explain the difference in results.

An alterantive explanation for the disparity pertains to the fact that private police are separately governed from the public police and the two organizations may have distinct goals. Prior studies that demonstrate substantial short-run effects of changes in police presence focus on

12 The full set of results is available upon request. 
contexts where there is central management of enforcement levels across the entire jursidiction. In this study, both the CPD and the UCPD provide enforcement services simultaneously and without direct coordination. The CPD could respond strategically to an expansion of the UCPD in a variety of ways - by cutting back its presence in the newly patrolled areas, leading to a partial displacement of the new private police, by expanding presence in the areas immediately surrounding the expansion zone, in an effort to contain spillover effects, or both. Our short-run results would be expected if the public police alter their patrol patterns in a way that negates the effects of the boundary expansion.

However, given that we ultimately observe differences in crime based on the UCPD boundaries, any explanation that relies on the compensatory behavior by the CPD requires that such behavior be only temporary, and there is no obvious explanation for why such differences could persist for several years but not indefintely. Moreover, a number of factors would have made it difficult for CPD to appreciably reduce its patrol effort in repsonse to the expansions. There was strong community pressure to increase police presence when both expansions occurred, and so a rollback by the CPD would likely have met with community resistance. Also, the patrol structure of the CPD, which is organized around geogrpahic beats that have reamined fairly constant over time, would complicate efforts to diminsh patrol in a narrowly defined area without endangering neighboring blocks not patrolled by the UCPD. Finally, there is little evidence from media accounts or our discussions with individuals in the UCPD or CPD that suggest that the CPD engages in such strategic behaivor. Thus, while acknowleding the possiblity that the patterns we observe might reflect displacement, we do not find this to be a likely explanation for our findings. More generally, however, the issue of crowding out is an 
important one that is specifically relevant when considering the impacts of private rather than public police.

A related possiblity is that private police crowd out private precautionary measures. If the expansions reduced investment in alarm systems and led to citizens in the affected areas to be more willing to engage in risky behaviors such as walking alone at night, or otherwise diminshed private precaution, then net impact might be small even if police themselves do have some salutary effect. Lacking data on private precaution, we are unable to test this hypothesis directly. However, the timing and magnitude of the effects we observe would seem to disfigure private crowding out as an explanation - under this explanation, individuals in the expansion areas would need to reduce private precautionary measures fairly quickly to fully offset the effects of private patrols, but then over time increase private precautionary behavior so as to render the effects of police eventually detectible. The costs of the private police were borne by the university rather than neighborhood residents, so the expansions had no direct influence on the budget constraints affecting potential victims. Moreover, it seems unlikely that private precaution could be sufficiently protective so as to account for changes in crime of $50 \%$ or more.

One important difference between our Chicago context and the policing variation studied in past research is that introduction of private police in Chicago were expected to be relatively permanent, whereas in the other studies, policing changes were likely to be transient. One possiblity is that criminals might be willing to displace their activity temporarily at fairly low cost, but may have difficulty making permanent career changes. For example, individuals who rely on drug selling or acquisitive crimes for income may be able to defer criminal activity during periods of high police scrutiny so long as such periods are sufficiently brief; at some point, however, the need for income will override the risk of capture. Under this job-centric view 
of criminal activity, criminals respond to events such as those in documented in London by Draca, Machin, and Witt ( 2011) by taking a "vacation" from crime, leading to short-run drops in crime, but crime reasserts itself once the period of hightened enforcement has passed. In Chicago, in contrast, when expansions occur, criminals may recognize the permanence of the new arrangement and thus not respond by taking "vacations", leading to little short-run effect on crime patterns. A permanent increase in enforcement reduces the returns to being a criminal in the targeted area, however, so over time criminals sustitute to other careers or other locations, leading to the larger long-run effects we demonstrate. If this model explains our findings, one implication is that the speed of "job" adjustment is fairly slow, as we do not find signficant changes in crime when boundaries are changed even several years post-expansion. The model, if also correct, would imply that private police forces may require sustained investment over a long period time to be fully effective.

Our analysis also connects with the extensive popular discussion and academic debate surrounding the problem of crime and violence at institutions of higher education. Over the past few decades, the nature of the discourse has changed, as campus crime has evolved into a major social issue, requiring federal and state political action (Sloan and Fisher 2010). Colleges and universities face pressure from governments, students, and activist organizations to ensure campus safety. Campus law enforcement agencies are a central component of crime reduction efforts, yet the effect of campus law enforcement agencies on campus crime and violence has received scant attention in the empirical literature.

We note that in this study, as in all studies of the effect of enforcement effort that rely on geographic comparisons, it is impossible to know with certainty whether the additional police reduced crime in an absolute sense or merely displaced it to other areas. Displacement is of 
particular concern for public police because displacement results in a reallocation of workload across different geographic units with no net benefit for the department as a whole. For private police, the calculus is more complicated—because private police exist to further the interests of a particular constituency, to the extent that private police increase safety for their constituents, even at the cost of displacing crime to others, they may view themselves as successfully fulfilling their mission. Additionally, if willingness to invest in private police is driven by differences in the costs of victimization, then private police may promote a form of allocative efficiency even if they primarily displace rather than prevent crime.

\section{Conclusions}

This study demonstrates that investment in private security can have a meaningful impact on serious crime in surrounding areas over a long-run. Using two approaches to examine the impact of a privately-funded police force on neighborhood safety - a natural experiment in which the authority of the University of Chicago Police Department expanded jurisdictional boundaries in 2001 and 2004 to capture the short-term effect of their expansion on crime, and a geographic regression discontinuity approach to capture the longer-term effect, we show that private police do not have a measurable effect in the short- to medium-run, but in the long run, additional policing reduced violent crime by over $50 \%$ in the target areas.

We offer several potential explanations for these contradictory findings across our two research designs. First, there could be a substitution effect with the private police simply replacing the public police services in the new area in the short run. Second, there could be a substitution effect with other forms of self-protection (such as alarms, private guards, or selective avoidance/seeking of crime-prone/improbable areas), such that households and businesses reduced spending in security when UCPD expanded. Third, and perhaps most likely, there may 
be a long delay of the effect of the extra police on crime because it takes a long time to change the crime dynamics of neighborhoods, as criminals adjust to permanent increases in the cost of committing crime.

The University of Chicago's experience shows that campus law enforcement may be a cost-effective means of addressing crime and violence in higher education settings, at least with a sustained investment over many years. The implications of these findings may be particularly important as Congress turns their eyes once again towards campus safety and crime prevention. In the UCPD's jurisdiction, only thirty-four percent of violent crimes occurred on campus. The University of Chicago is not an outlier in this respect, as nationwide, more crimes involving college students occur off-campus than on. Expanding the jurisdiction of campus police departments, and allowing officers to patrol beyond their borders, may be integral to their success. More broadly, our research suggests that private police can be as effective at crime control as traditional police, at least in some circumstances. Additional efforts to rigorously measure the impacts of private police are warranted so as to allow us to better identify the contexts in which private police matter most for public safety. 


\section{References}

Becker, Gary S. 1993. "Nobel lecture: The economic way of looking at behavior." Journal of political economy:385-409.

Brooks, Leah. 2008. "Volunteering to be taxed: Business improvement districts and the extragovernmental provision of Public Safety." Journal of Public Economics 92:388-406.

Buonanno, Paolo, and Giovanni Mastrobuoni. 2012. "Police and crime: Evidence from dictated delays in centralized police hiring."

Bureau of Labor Statistics. 2013. "Occupational Employment and Wages, May 2013."

Chalfin, Aaron, and Justin McCrary. 2013. The effect of police on crime: New evidence from US cities, 1960-2010. National Bureau of Economic Research.

Chicago Tribune. 2014. "Crime in Chicagoland." http://crime.chicagotribune.com/chicago/community/hyde-park.

Cook, Philip J. 1986. "The demand and supply of criminal opportunities." Crime and justice:127.

Cook, Philip J., and John MacDonald. 2011. "Public Safety Through Private Action: An Economic Assessment of BIDS." The Economic Journal 121:445-462.

Corman, Hope, and H Naci Mocan. 1996. A time-series analysis of crime and drug use in New York City. National Bureau of Economic Research.

D’Alessio, Stewart J, David Eitle, and Lisa Stolzenberg. 2005. "The impact of serious crime, racial threat, and economic inequality on private police size." Social Science Research 34 (2):267-282.

Di Tella, Rafael, and Ernesto Schargrodsky. 2004. "Do police reduce crime? Estimates using the allocation of police forces after a terrorist attack." The American Economic Review 94 (1):115-133.

Draca, Mirko, Stephen Machin, and Robert Witt. 2011. "Panic on the streets of london: Police, crime, and the july 2005 terror attacks." The American Economic Review:2157-2181.

Evans, William N, and Emily G Owens. 2007. "COPS and Crime." Journal of Public Economics 91 (1):181-201.

Gove, Walter R, Michael Hughes, and Michael Geerken. 1985. "Are Uniform Crime Reports A Valid Indicator Of The Index Crimes? An Affirmative Answer With Minor Qualifications*." Criminology 23 (3):451-502. 
Janosik, Steven M, and Dennis E Gregory. 2003. "The Clery Act and its influence on campus law enforcement practices." Journal of Student Affairs Research and Practice 41 (1):182-199.

Joh, Elizabeth E. 2005. "Conceptualizing the private police." Utah L. Rev.:573.

Jones, Trevor, and Tim Newburn. 1999. "Urban Change and Policing: Mass Private Property ReConsidered." European journal on criminal policy and research.

Kakalik, James S, and Sorrel Wildhorn. 1971. "Private Police in the United States."

Kempa, Michael, Philip Stenning, and Jennifer Wood. 2004. "Policing Communal Spaces A Reconfiguration of the 'Mass Private Property'Hypothesis." British Journal of Criminology 44 (4):562-581.

Klick, Jonathan, and Alexander Tabarrok. 2005. "Using Terror Alert Levels to Estimate the Effect of Police on Crime*." Journal of Law and Economics 48 (1):267-279.

Larson, Jordan. 2012. "A brief history of the UCPD." Chicago Maroon, March 25, 2012. http://chicagomaroon.com/2012/05/25/a-brief-history-of-the-ucpd/.

Levitt, Steven D. 1997. "Using electoral cycles in police hiring to estimate the effect of police on crime." The American Economic Review:270-290.

Levitt, Steven D. 2002. "Using electoral cycles in police hiring to estimate the effects of police on crime: Reply." American Economic Review:1244-1250.

MacDonald, John, Daniela Golinelli, Robert J Stokes, and Ricky Bluthenthal. 2010. "The effect of business improvement districts on the incidence of violent crimes." Injury prevention 16 (5):327-332.

MacDonald, John, Jonathan Klick, and Ben Grunwald. 2012. "The Effect of Privately Provided Police Services on Crime." Available at SSRN 2171038.

Marvell, Thomas B, and Carlisle E Moody. 1996. "Specification Problems, Police Levels, And Crime Rates*." Criminology 34 (4):609-646.

McCrary, Justin. 2002. "Using electoral cycles in police hiring to estimate the effect of police on crime: Comment." American Economic Review:1236-1243.

Nalla, Mahesh K, and Cedrick G Heraux. 2003. "Assessing goals and functions of private police." Journal of Criminal Justice 31 (3):237-247.

Northwestern Univeristy Center for Healthcare Equity. 2011. "Demographics." http://chicagohealth77.org/characteristics/demographics/.

Peak, Kenneth J, Emmanuel P Barthe, and Adam Garcia. 2008. "Campus Policing in America A Twenty-Year Perspective." Police Quarterly 11 (2):239-260. 
Reaves, Brian A. 2008. Campus law enforcement, 2004-05: US Department of Justice, Office of Justice Programs.

Savas, E.S. 1987. "Privatization and Prisons." Vanderbilt L. Rev. 40.

Shearing, Clifford D, and Philip C Stenning. 1981. "Modern private security: its growth and implications." Crime and justice:193-245.

Shearing, Clifford D, and Philip C Stenning. 1983. "Private security: implications for social control." Social Problems:493-506.

Sklansky, David A. 1999. "The Private Police." UCLA L. Rev. 1165.

Sloan, John J., and Bonnie S. Fisher. 2010. The Dark Side of the Ivory Tower: Campus Crime as a Social Problem: Cambridge University Press.

Spitzer, Steven, and Andrew T Scull. 1977. "Privatization and capitalist development: the case of the private police." Social Problems:18-29.

Stenning, Philip C. 2000. "Powers and accountability of private police." European journal on criminal policy and research 8 (3):325-352.

University of Chicago Department of Safety and Security. 2013. 2012 Annual Report. Chicago: University of Chicago.

Wakefield, Alison. 2002. "The public surveillance functions of private security." Surveillance \& Society 2 (4).

Wakefield, Alison. 2008. "Private policing: a view from the mall." Public administration 86 (3):659-678. 
Tables

Table(s)

Tables

Tables

(

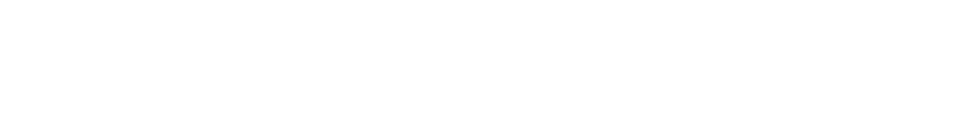
.

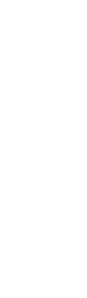

-

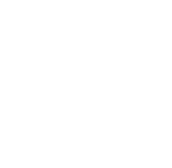


Table 1. Descriptive statistics for UCPD patrol zone

\begin{tabular}{|c|c|c|c|c|c|}
\hline & $\begin{array}{c}\text { Average for } \\
\text { block groups } \\
\text { within UCPD } \\
\text { patrol zone }\end{array}$ & SD & $\begin{array}{c}\text { Estimated } \\
\text { change } \\
\text { at the } \\
\text { border }\end{array}$ & $\begin{array}{c}\text { SE } \\
\text { of } \\
\text { estimate } \\
\end{array}$ & $\begin{array}{c}\mathrm{P}- \\
\text { value }\end{array}$ \\
\hline Total Population & 1185.19 & 493.46 & -167.98 & 80.17 & $0.04 *$ \\
\hline Fraction Black & 0.76 & 0.29 & -0.01 & 0.05 & 0.84 \\
\hline Fraction Hispanic & 0.03 & 0.04 & -0.01 & 0.01 & 0.43 \\
\hline Fraction young & 0.06 & 0.06 & -0.01 & 0.01 & 0.55 \\
\hline Fraction recently moved & 0.19 & 0.10 & 0.02 & 0.03 & 0.42 \\
\hline Fraction living alone & 0.44 & 0.16 & -0.03 & 0.03 & 0.40 \\
\hline $\begin{array}{l}\text { Fraction of children not living with } \\
\text { parents }\end{array}$ & 0.14 & 0.15 & 0.05 & 0.03 & 0.08 \\
\hline Fraction married & 0.28 & 0.11 & 0.01 & 0.03 & 0.84 \\
\hline Fraction HS dropout & 0.13 & 0.11 & 0.00 & 0.02 & 0.84 \\
\hline Median household income & 37,990 & 20,736 & 3034 & 3645 & 0.41 \\
\hline Fraction with no earnings & 0.27 & 0.15 & -0.03 & 0.03 & 0.26 \\
\hline Fraction receiving SSI & 0.10 & 0.09 & 0.01 & 0.02 & 0.76 \\
\hline $\begin{array}{l}\text { Fraction receiving public } \\
\text { assistance }\end{array}$ & 0.04 & 0.05 & -0.01 & 0.01 & 0.11 \\
\hline Fraction veterans & 0.06 & 0.04 & 0.00 & 0.01 & 0.86 \\
\hline Fraction unemployed & 0.19 & 0.11 & 0.00 & 0.02 & 0.81 \\
\hline Fraction not in labor force & 0.39 & 0.13 & -0.01 & 0.03 & 0.61 \\
\hline Number of housing units & 647.77 & 293.93 & -61.63 & 55.95 & 0.27 \\
\hline Rental share of housing stock & 0.69 & 0.18 & -0.03 & 0.04 & 0.54 \\
\hline Fraction of houses vacant & 0.21 & 0.13 & 0.03 & 0.02 & 0.17 \\
\hline Median \# rooms & 4.61 & 0.87 & 0.22 & 0.18 & 0.23 \\
\hline Share of houses that are single unit & 0.16 & 0.12 & 0.01 & 0.02 & 0.83 \\
\hline Median contract rent & 751.39 & 238.94 & 127.80 & 38.73 & $0.00 * *$ \\
\hline Median house value & 255,037 & 108,085 & 24,583 & 20,942 & 0.24 \\
\hline Fraction low income & 0.12 & 0.07 & -0.01 & 0.02 & 0.58 \\
\hline
\end{tabular}




\begin{tabular}{lllllc}
\hline \% below poverty line & 0.29 & 0.12 & -0.07 & 0.03 & $0.01^{* *}$ \\
\% non-citizen & 0.05 & 0.05 & 0.01 & 0.01 & 0.51 \\
\% disabled & 0.15 & 0.06 & -0.01 & 0.01 & 0.51 \\
\hline
\end{tabular}

${ }^{* *} \mathrm{p}<0.01,{ }^{*} \mathrm{p}<0.05$. The unit of observation is a block group and the sample size is 1,065 .

Table 2. Difference-in-Difference Results of UCPD Effect on Block-level Monthly Crime

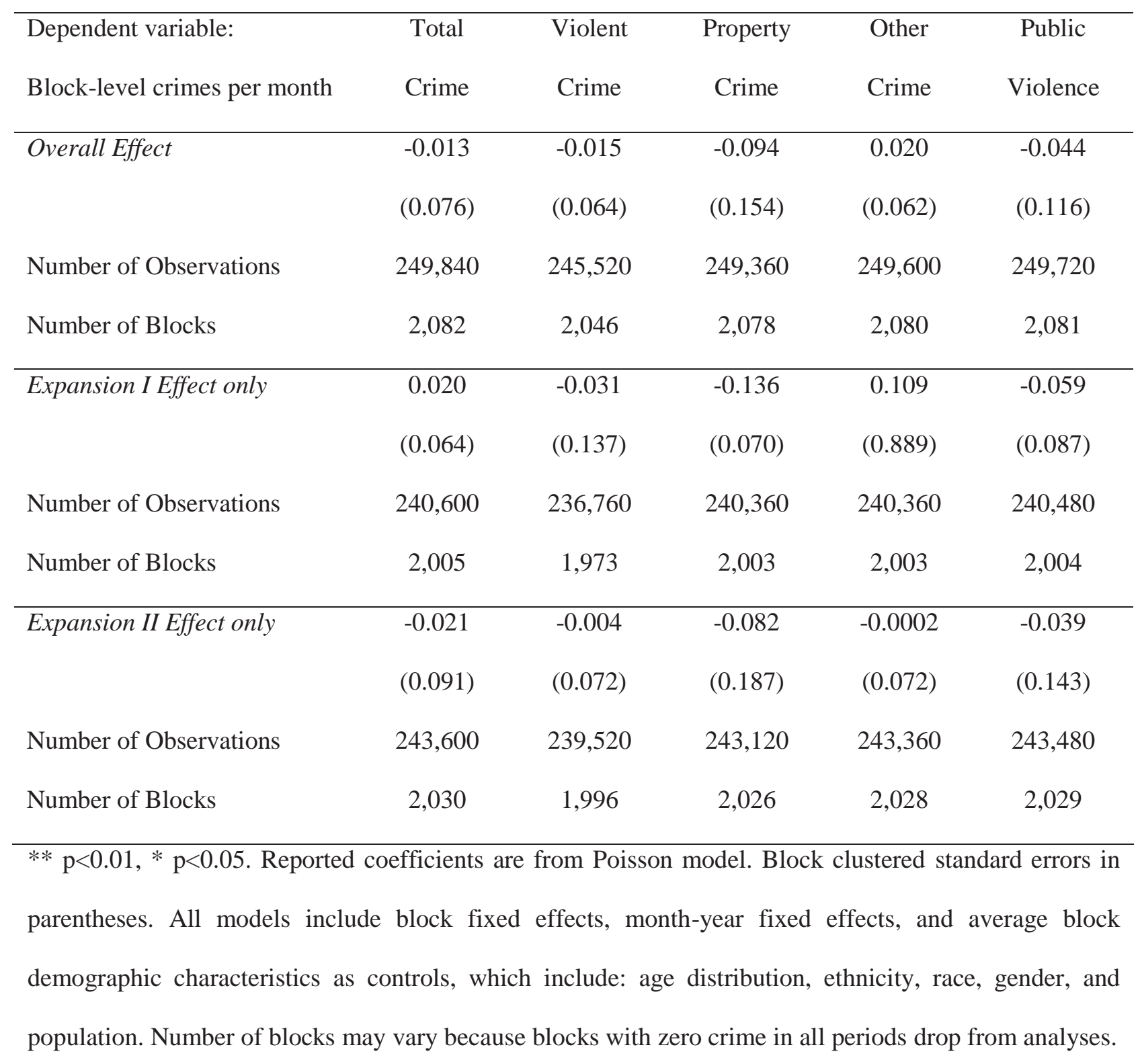


Table 3. Geographic Regression Discontinuity Results

(1)

\begin{tabular}{lc}
\hline All Crime & $68.70^{*}$ \\
& $(35.69)$ \\
Observations & 1065 \\
\hline Violent Crime & $9.72^{* *}$ \\
& $(3.52)$ \\
Observations & 1065 \\
\hline Property Crime & 11.58 \\
& $(10.83)$ \\
Observations & 1065 \\
\hline Public Violence & 47.21 \\
& $(25.00)$ \\
Observations & 1065 \\
\hline
\end{tabular}

${ }^{* *} \mathrm{p}<0.01,{ }^{*} \mathrm{p}<0.05$. Table notes: (1) base model (local linear regression) 
Table 4. Robustness Check for Geographic Regression Discontinuity Results

\begin{tabular}{|c|c|c|c|c|c|c|c|c|}
\hline & (1) & (2) & (3) & (4) & (5) & (6) & (7) & (8) \\
\hline \multirow[t]{2}{*}{ All Crime } & $0.55^{*}$ & 58.69 & $83.20 *$ & 65.07 & 86.94 & 44.42 & 57.67 & $80.55 * *$ \\
\hline & $(0.29)$ & $(34.80)$ & (41.97) & (34.52) & (48.52) & (58.62) & $(52.44)$ & (18.14) \\
\hline Observations & 1065 & 1065 & 1065 & 1065 & 1065 & 451 & 251 & 1065 \\
\hline \multirow[t]{2}{*}{ Violent Crime } & $0.63 * *$ & $8.66 * *$ & $11.30 * *$ & $8.27 * *$ & $11.60 *$ & 7.01 & 9.64 & $6.87 * *$ \\
\hline & $(0.24)$ & (3.46) & $(4.22)$ & (3.24) & $(4.82)$ & $(4.82)$ & (5.05) & (1.63) \\
\hline Observations & 1065 & 1065 & 1065 & 1065 & 1065 & 451 & 251 & 1065 \\
\hline \multirow{3}{*}{$\begin{array}{l}\text { Property } \\
\text { Crime }\end{array}$} & 0.36 & 10.32 & 15.96 & 7.29 & 18.22 & 5.35 & 8.84 & $17.50 * *$ \\
\hline & & & & & & & & \\
\hline & $(0.26)$ & (10.53) & $(12.56)$ & (9.63) & (12.90) & (19.26) & (14.08) & $(5.40)$ \\
\hline Observations & 1065 & 1065 & 1065 & 1065 & 1065 & 451 & 251 & 1065 \\
\hline \multirow{3}{*}{$\begin{array}{l}\text { Public } \\
\text { Violence }\end{array}$} & 0.49 & 27.02 & 43.66 & 49.51 & 37.79 & -1.67 & 51.10 & $71.38 * *$ \\
\hline & & & & & & & & \\
\hline & $(0.27)$ & (23.85) & $(30.00)$ & $(24.84)$ & $(36.20)$ & (49.18) & (32.73) & (12.04) \\
\hline Observations & 1065 & 1065 & 1065 & 1065 & 1065 & 451 & 251 & 1065 \\
\hline
\end{tabular}

Table notes: (1) logged outcomes, (2) include covariates, (3) robust model. (4) quadratic polynomial in distance, (5) cubic polynomial in distance (6) omit border (7) near border only (8) alternative distance metric. 
Figures 


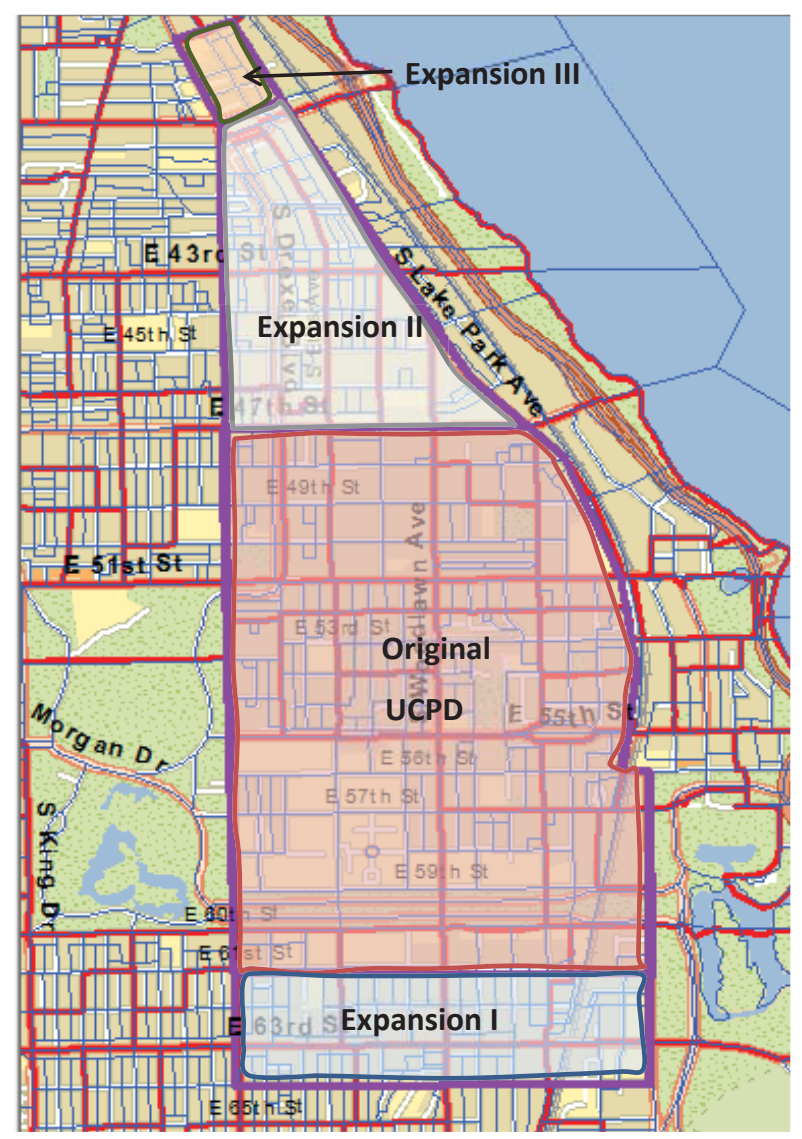

Figure 1. UCPD Extended Patrol Map 


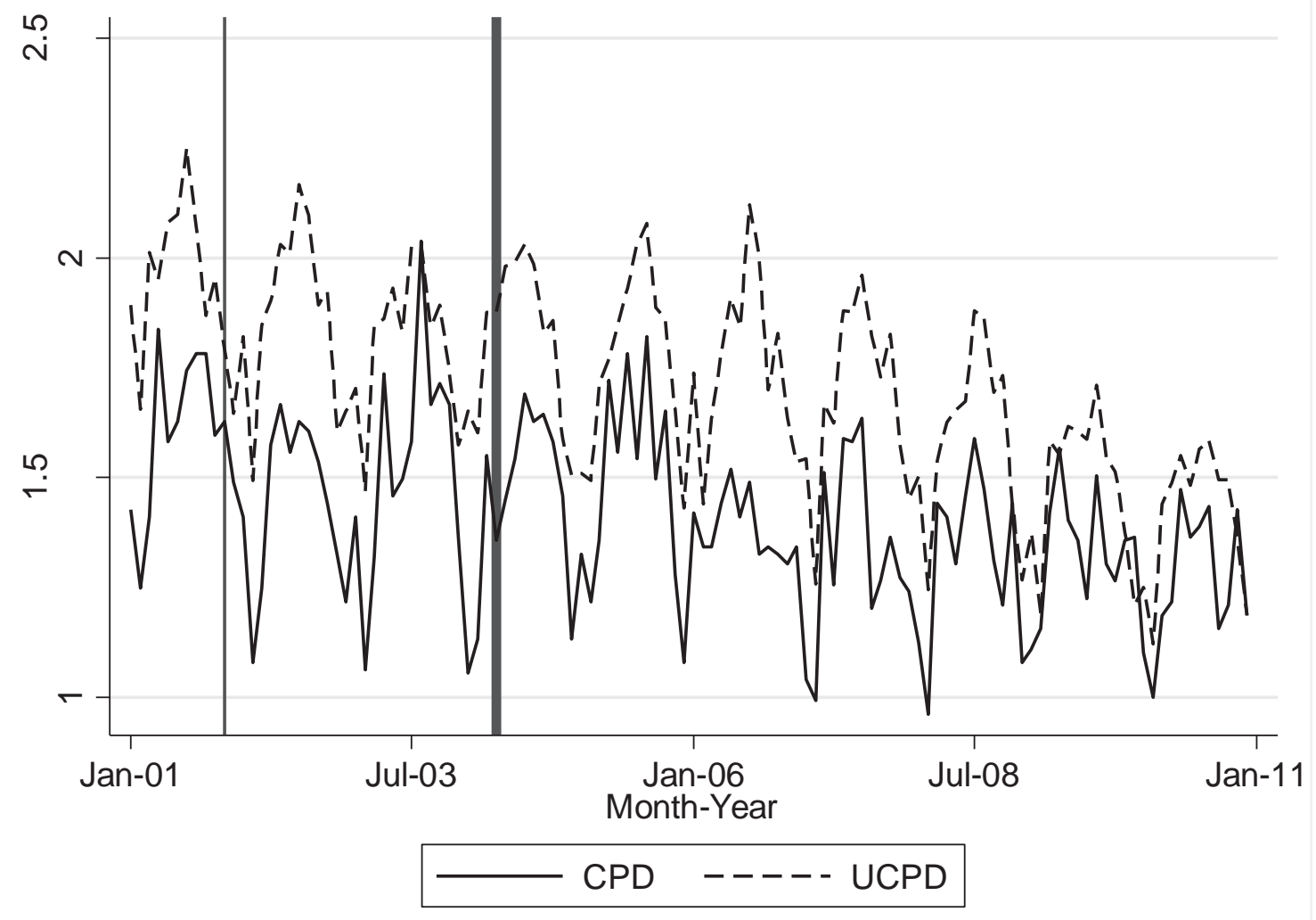

Figure 2. Mean Total Crimes per Block per Month in UCPD and CPD Areas Analyzed 


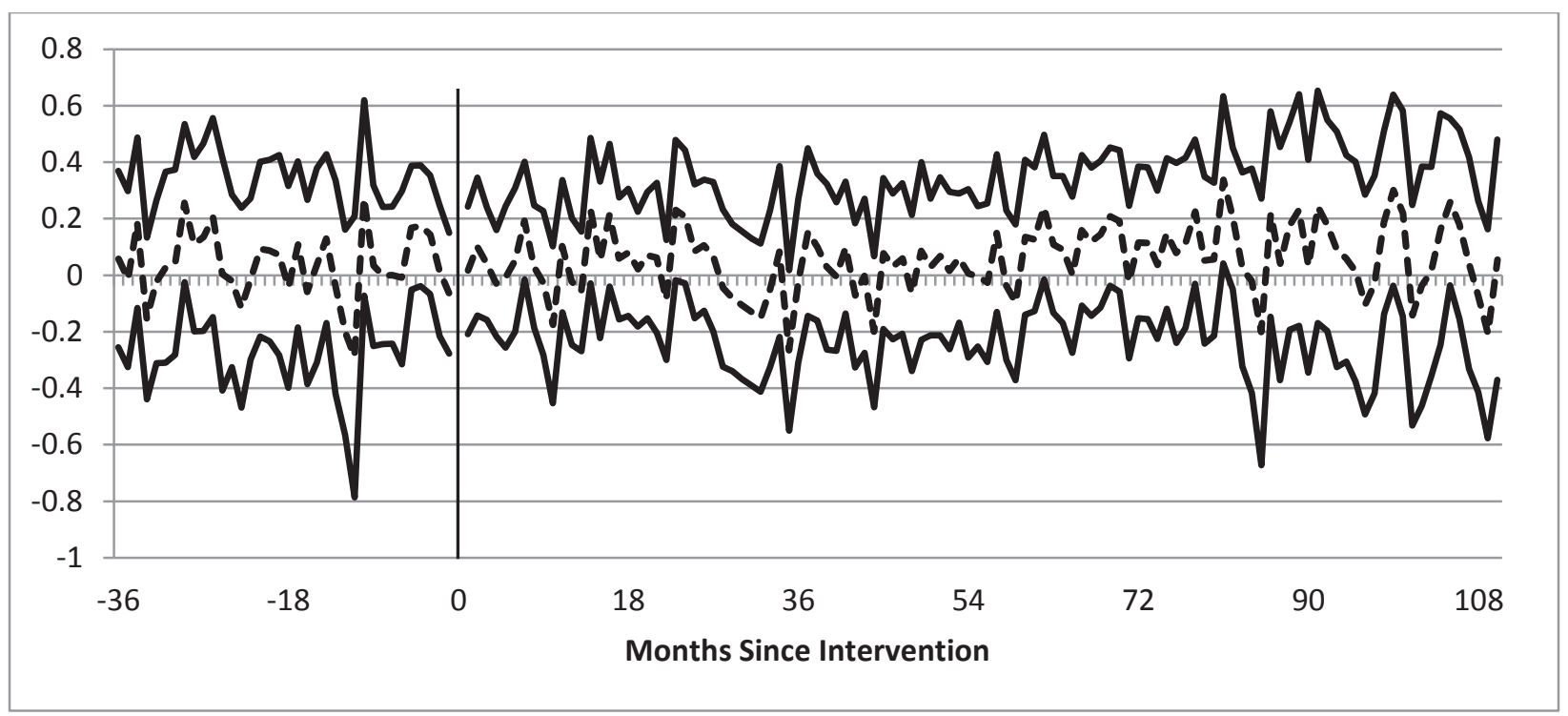

Figure 3: Results from Event Study Analysis of Jurisdiction Expansion, (2001-2010) 


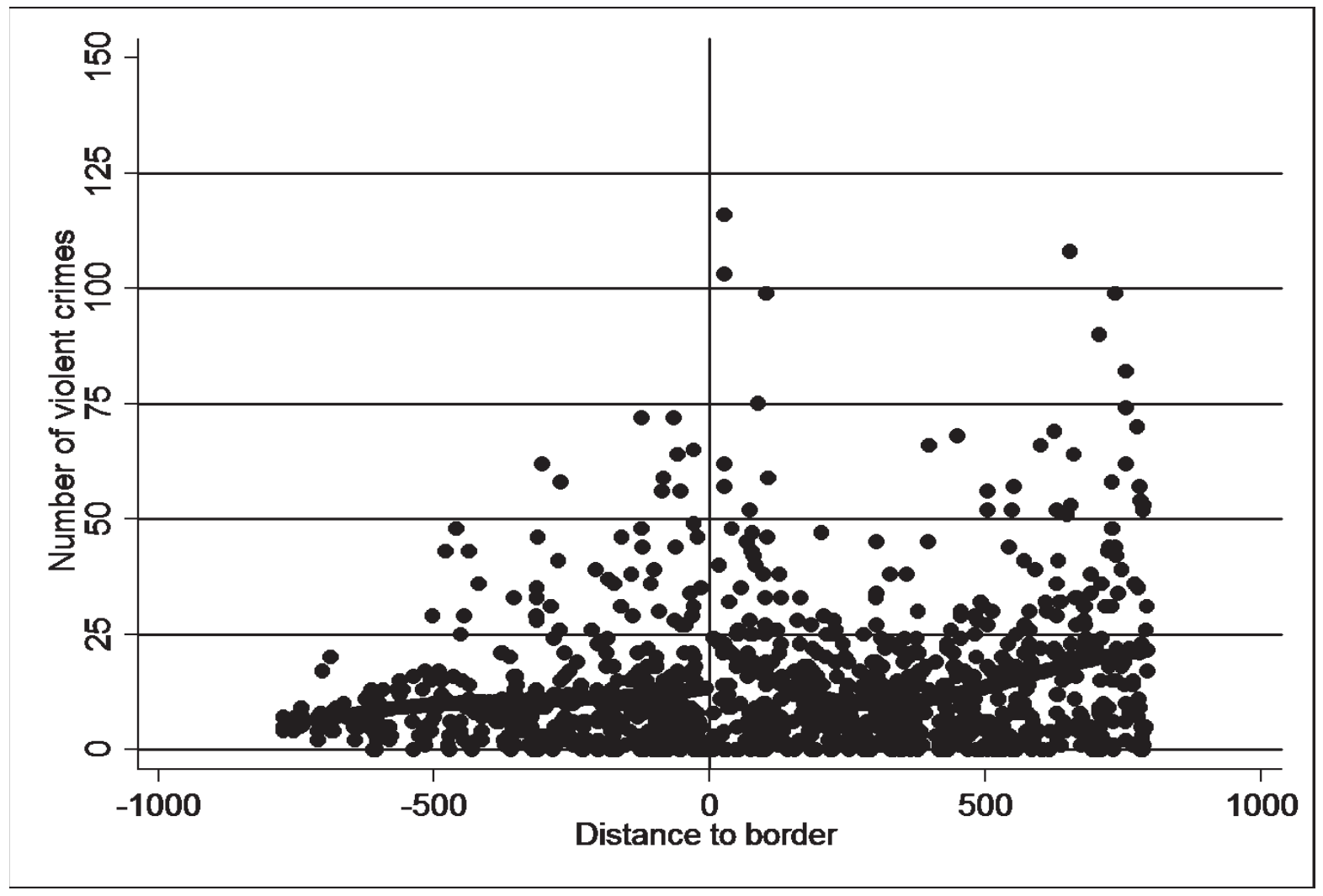

Figure 4. Violent crime by block distance from patrol boundary 